\title{
Hormones and bone
}

Francisco Bandeira', Marise Lazaretti-Castro², John P. Bilezikian ${ }^{3}$

$\mathrm{D}$ uring childhood, skeletal growth velocity and growth plate activities are largely dependent on growth hormone, IGF-1 and thyroid hormone, along with the calcium-regulating hormones, parathyroid hormone and vitamin D. Altogether, the hormonal influence on optimal skeletal growth and peak bone mass is enormously important.

Sex hormones have considerable influence not only on bone density, but also on bone quality. Data from studies of long bone geometry have shown that both testosterone and estradiol influence the cross-sectional area. Testosterone acts mainly on the periosteal surface while estradiol appears to influence bone growth on the endosteal surface (1). The influence of estrogen on the male skeleton has been shown in the context of growth and epiphyseal maturation through studies of men with an inability to produce estrogen because of aromatase deficiency. In addition, men with genetic predisposition to have greater aromatase activity through polymorphisms of the CYP19 gene have higher estrogen levels and less age-related bone loss (2-3). Moreover, crosssectional studies have emphasized the importance of estrogen levels in maintaining male skeletal mass (4).

Parathyroid hormone $(\mathrm{PTH})$ is unique in its actions on bone strength as it may have profoundly negative or positive effects, depending on the manner in which it is secreted or administered. From a therapeutic point of view, intermittent, low dose administration of PTH is associated with important anabolic effects on the skeleton (5) that have been demonstrated in postmenopausal women and in men (6). In primary hyperparathyroidism, on the other hand, the chronically high levels of PTH are associated with a proclivity for bone loss at the distal $1 / 3$ radius, a site that is comprised mainly of cortical bone $(7,8)$. Marked improvements in bone mass are seen following successful parathyroidectomy in severe primary hyperparathyroidism in a state of hungry bones with hypocalcemia and secondary hyperparathyroidism (9). Improvements are also seen in subjects whose primary hyperparathyroidism is characterized primarily by densitometric and mild biochemical abnormalities (10). Vitamin D is becoming widely recognized as a pivotally important calcium regulating-hormone. Suboptimal serum concentrations of 25-hydroxivitamin $\mathrm{D}$ have been found in various populations worldwide, including those in countries with an abundance of sunlight. These observations challenge previous notions that sunny climates are associated with normal vitamin D levels $(11,12)$. The epidemic of vitamin D deficiency has led to recognition that it is involved in many important non-skeleton systems that govern functions of muscle, cognition, vision, heart, immunity, insulin sensitivity and cancer risk (12-14).

Obesity is becoming the center of attention in view of adipocyte hormonal products that have important skeletal properties (15). In this regard, controversial issues related to hormones and bone strength arise, and some data suggest that the type of body fat distribution whether central or peripheral may have different effects on bone metabolism related to the degree of inflammation, insulin resistance and adipocyte hormone secretion. Although very high insulin levels present in some rare insulin-resistant states (16) may be anabolic to bone, data have emerged that leptin and insulin resistance may nega-
${ }^{1}$ Professor de Medicina e de Epidemiologia Clínica, coordenador da Divisão de Endocrinologia e Diabetes, Hospital Agamenon Magalhães, Ministério da Saúde, Faculdade de Ciências Médicas, Universidade de Pernambuco (UFPE), Recife, PE, Brasil ${ }^{2}$ Professora de Endocrinologia, coordenadora do Ambulatório Ósseo, Faculdade de Medicina, Universidade Federal de São Paulo (Unifesp/EPM), São Paulo, SP, Brasil ${ }^{3}$ Professor de Medicina e Farmacologia Clínica, coordenador da Divisão de Endocrinologia e Diabetes, Hospital Presbiteriano, Columbia University, Nova Iorque, Estados Unidos

Correspondence to: Francisco Bandeira Av. Rui Barbosa, 1.435 52050-450 - Recife, PE, Brasil fbandeira@gmail.com 
tively influence BMD (Bone Mineral Density) in obese patients at the time of adolescent bone accrual (17).

In this special issue of the Brazilian Archives of Endocrinology (ABE\&M) through the Brazilian Society for Endocrinology and Metabolism, these and other issues are covered. We would like to express our gratitude to all the contributors to this supplement, and very much hope that it will offer you an opportunity to update your knowledge in this fascinating and fast-moving field.

\section{REFERENCES}

1. Wang $\mathrm{Q}$, Alem M, Nicholson PH, Hallen JM, Alatalo SJ, Ohlsson C, et al. Differential effects of sex hormones on peri- and endocortical bone surfaces in pubertal girls. J Clin Endocrinol Metab. 2006;91:277-82.

2. Gennari L, Nuti R, Bilezikian JP. Aromatase activity and bone homeostasis in men. J Clin Endocrinol Metab. 2004;89:5898-907.

3. Bilezikian JP. What's good for the goose's skeleton is good for the gander's skeleton. J Clin Endocrinol Metab. 2006;91:1223-5.

4. Gennari L, Khosla S, Bilezikian JP. Estrogen and fracture risk in men. J Bone Miner Res. 2008:23:1548-51.

5. Bilezikian JP, Matsumoto T, Bellido T, Khosla S, Martin J, Recker $\mathrm{R}$, et al. Targeting bone remodeling for the treatment of osteoporosis: summary of the proceedings of an ASBMR workshop. J Bone Miner Res. 2009;24(3):373-85.

6. Girotra M, Rubin MR, Bilezikian JP. Anabolic skeletal therapy for osteoporosis. Arq Bras Endocrinol Metab. 2006;50:745-54.
7. Bandeira F, Griz LH, Bandeira C, Pinho J, Lucena CS, Alencar C, et al. Prevalence of cortical osteoporosis in mild and severe primary hyperparathyroidsim and its relationship with bone markers and vitamin D status. J Clin Densitom. 2009;12:195-9.

8. Silverberg SJ, Shane E, De La Cruz L, Dempster DW, Feldman F, Seldin D, et al. Skeletal disease in primary hyperparathyroidism. J Bone Min Res. 1989;4:283-91.

9. Bandeira F, Griz L, Caldas G, Bandeira C, Freese E. From mild to severe primary hyperparathyroidism- the Brazilian experience. Arq Bras Endocrinol Metab. 2006;50:657-63.

10. Rubin MR, Bilezikian JP, McMahon DJ, Jacobs T, Shane, E, Siris E, et al. The natural history of primary hyperparathyroidism with or without parathyroid surgery after 15-years. J Clin Endocrinol Metab. 2008;93:3462-70.

11. Bandeira F, Griz L, Dreyer P, Eufrasino C, Bandeira C, Freese E. Vitamin D deficiency: a global perspective. Arq Bras Endocrinol Metab. 2006;50:640-6.

12. Holick MF. Vitamin D deficiency. N Eng J Med. 2007;19;357:266-81.

13. Lapp JL. Vitamin D: bone health and beyond. Am J Lifestyle Med. 2009;3:386-93.

14. Pedrosa MA, Lazaretti-Castro $M$. Role of vitamin $D$ in the neuromuscular function. Arq Bras Endocrinol Metab. 2005;49:495-502.

15. Elefteriou F, Ahn JD, Takeda S, Starbuck M, Yang X, Liu X, et al. Leptin regulation of bone resorption by the sympathetic nervous system and CART. Nature. 2005;434:514-20.

16. Bandeira F, Miranda CR, Waechter C, Bandeira ME. High bone mass associated with Berardinelli lipodistrophy. Endocr Pract. 2007;12:764-9.

17. Prado WL, Piano A, Lazaretti-Castro, Mello MT, Stella SG, Tufik S, et al. Relationship between bone mineral density, leptin and insulin concentration in Brazilian obese adolescents. J Bone Miner Metab. 2009;27:613-9. 